Vorontsova, A., Vasylieva, T., Bilan, Y., Ostasz, G., Mayboroda, T. (2020). The influence of state regulation of education for achieving the sustainable development goals: case study of Central and Eastern European countries. Administratie si Management Public, 34, 6-26, DOI: $10.24818 / \mathrm{amp} / 2020.34-01$

\title{
The influence of state regulation of education for achieving the sustainable development goals: case study of Central and Eastern European countries
}

\author{
Anna VORONTSOVA ${ }^{1}$, Tetiana VASYLIEVA ${ }^{2}$, Yuriy BILAN $^{3}$, \\ Grzegorz OSTASZ $^{4}$, Tetyana MAYBORODA ${ }^{5}$
}

\begin{abstract}
Nowadays, we are becoming more and more convinced that the educational sphere cannot be underestimated and we do not pay enough attention to its development. After all, it is responsible for the formation of a well-developed and indifferent personality both in social and environmental problems, as well as qualified workers in accordance with the modern requirements of the world. In this context, optimal government regulation of education will contribute not only to economic growth and the acquisition of intellectual capital of the country, which will ensure its competitiveness and innovations, but also to balanced sustainable development, which is important on a planetary scale. This article is devoted to the analysis of the interrelation between indicators of state regulation of the education sector and the achievement of sustainable development goals. For this purpose, the method of integral indicators with elements of the method of principal components (for each sustainable development goal) was used, as well as regression models with fixed effects (to determine the presence and nature of the link between state regulation of the education and the goals of sustainable development). The basis for the study was the official data of 14 countries of Central and Eastern Europe for 2006-2016 years, which is presented as panel data. The obtained results made it possible to confirm the existence of such interrelation, where the most effective state instrument proved to be the state financing of the education sector.
\end{abstract}

Keywords: state regulation of education, sustainable development goals, state financing of education, Central and Eastern Europe countries.

JEL: I20, I28, Q01

DOI: $10.24818 / \mathrm{amp} / 2020.34-01$

${ }^{1} \mathrm{PhD}$, Academic and Research Institute of Business Technologies "UAB", Sumy State University, Sumy, Ukraine, email: a.vorontsova@uabs.sumdu.edu.ua

${ }^{2}$ Doctor of science, Prof., Oleg Balatskyi Academic and Research Institute of Finance, Economics and Management, Sumy State University, Sumy, Ukraine, email: tavasilyeva@fem.sumdu.edu.ua

${ }^{3}$ Doctor of science, Prof., University of Social Sciences, Lodz, Poland, email: yuriy_bilan @yahoo.co.uk

${ }^{4}$ Doctor of science, Prof., Faculty of Management, Rzeszów University of Technology, Rzeszów, Poland, email: gost@prz.edu.pl

${ }^{5} \mathrm{PhD}$, Sumy State University, Sumy, Ukraine, t.majboroda@management.sumdu.edu.ua 


\section{Introduction}

The education sector is an integral part of the country's national economy since it produces and forms such a resource as a qualified human capital, without which activity in any other sector is impossible. Besides, the right to get an education is one of the main human rights, approved at the international level in the Universal Declaration of Human Right and at the constitutional level of every observed country (Kubak et al., 2018). Considering such a global social and economic significance, the education sector was and remains one of the main economic spheres, the activity of which requires state intervention.

Nowadays, an essential vector of any country's development is to provide its sustainable development through implementation and adaptation of main ideas at the national level. In general, the sustainable development concept is based on the balancing of three key areas development: economic growth, social inclusion (Bayar et al., 2020; Androniceanu, 2019a) and environmental protection (Borocki et al., 2019). However, it is impossible to fulfil this task without the appropriate activities in the education sector. It determines the urgency of the selected topic, which consists in confirmation of the hypothesis regarding the link between education sector regulation and achievement of the sustainable development goals.

\section{Literature review}

The sustainable development conception was spread at the beginning of the 90s in XX century and firstly was officially used at the UNO conference in Rio de Janeiro, where "An Agenda For The 21st Century" (Agenda 21) was approved. Its formation was related to the people's understanding of the current limited resources, the economic development inefficiency and ecological problems aggravation that make the threat for the future (Androniceanu, 2019b). Later measures to extend the main postulates of the sustainable development conception and to implement the main ideas at the national level of the world countries were approved at the international community level. In this regard, the universal goals of sustainable development were investigated. At first, they were approved during 2000-2015 (8 goals), and then they were extended during 2016-2030 (17 goals), the main direction of which was oriented to the economic, social and ecological growth and the world countries' development.

The educational component is a meaningful constituent of the sustainable development conception, since it is distinguished not only as a global aim №4 but is widely observed among other indicators and tasks (Pryima et al., 2018; Kryk, 2016). At the beginning of the sustainable development conception introduction, much attention was paid to the environmental education, but soon its complex value was recognized at all levels of the sustainable development (Chapter 36, Agenda 21; Haseeb et al., 2019). It should be separately noted that within the framework of UNESCO, the global movement Education For All (EFA), which in 
future was shown and included to the sustainable development goals (Center for Global Development, 2006), was parallel developed with the sustainable development conception. Education is an important component of the social sphere (Bondar \& Paszkowski, 2019). It greatly defines the efficiency and quality at the state level, proved by studies of scientists, headed by Bilan Y. et al. (2019), Brychko \& Semenog (2018), Vasilyeva T. et al. (2018) and Pauhofova et al., 2018). Education is also one of the macroeconomic stability factors, which is demonstrated in its turn through the global competitiveness and effects the economic growth respectively (Bilan (a, b, d, e) et al., 2019; Vasilyeva et al., 2019 and 2014; Pikhotskyi et al., 2018, Lyeonov et al., 2018, Palienko 2018, Abaas, 2018, Kolosok, 2015; Nicolescu et al., 2020; Rahman et al., 2019). It is equally important that education forms the innovative potential of the national economy in the country (Kolosok et al., 2018, Peresadko et al., 2014), creative industry (Bilan (c) et al., 2019) or industry 4.0 (Bilan Y. (f) et al., 2019, Kohnová et al., 2019) corporate social responsibility (Serhii et al., 2014; Androniceanu, 2019c). Based on the fact that this research was carried out among Central and Eastern Europe countries, different sides regarding the development of their economies (fiscal and tax system, banking and entrepreneurial activity sphere, investment position) in the context of relationship with educational, innovation sector also has to take place (Bercu et al., 2019; Grenäãkovã et al., 2019; Raišienè et al., 2019; Bilan et al., 2018; Chygryn et al., 2018; Kolosok et al., 2018, Baburina et al., 2017; Androniceanu et al., 2020).

Due to the growing role of education in the modern world, more and more studies are being directed to the knowledge-economy sphere, which demonstrates its place change in the national economy and ecology system (Vaiciukevičiūtè et al., 2019, Skliar, 2018, Wierzbicka, 2018, Smaliukienè et al., 2017, Vovk, 2017, Jikia et al., 2017, Balcerzak, 2016, Lyeonov \& Liuta, 2016, Matošková, 2016, Marekha, 2016; Tamulevičienė \& Androniceanu, 2020). In general, many works of the native and foreign scientists were devoted to the study of the relationship between separate indicators of the state policy in the education sector (Kowalska, 2016, Mazurek \& Mielcová, 2019, Palascakova et al., 2019). In this case it is appropriate to research different modern instruments or forms of state policy, for example coopetition (Shvindina, 2019), public-private partnership (Zakharkin et al., 2019, Anatan, 2018), participatory financing (Petrushenko et al., 2017).

The most direct instrument of the state policy in the education sector is financing, the influence of which on the economic growth became the object for analysis in many scientific works (Pitoňákova, 2019, Rungsrisawat et al., 2019, Guziejewska \& Majdzińska, 2018, Kouassi, 2018, Golovchanskaya et al., 2018). The group of scientists, headed by Churchill S.A. (2017) investigated 29 studies about the relationship between government expenditure on education and economic growth. Besides they found a mostly positive relationship for developed countries and mostly statistically insignificant for less developed countries. The study of education financing peculiarities from the state and non-state sector (with the calculation of its necessary share) in OECD countries was studied by Vorontsova 
A. (2018). It let to analyze the influence of the expenditure for education on the social and economic development indicators in Ukraine (Vasylieva, 2017), that revealed a direct impact on the country's economic development, reduction of the income distribution inequality, increase of employment and reduction of unemployment (with 5 years lag), the country's globalization and competitiveness level growth and on the tax payment by citizens. Hypotheses about the financial provision impact of the education sector on the decrease of corruption, crime level and migration in the country, have been rejected. Similar research regarding the impact of higher education on socio-economic performance and development was carried out by Volchik, V., Oganesyan, A and Olejarz, T. (2018).

Other scientists (Benos, 2014, Mendy, 2018, Indiyati, 2018) focused their attention on the relationship of other indicators of the state education policy (enrolment rates, literacy rates, years of schooling) with economic development. Numerous works proved the positive influence of the education on reduction of poverty and growth of the income levels (Becker \& Chiswick, 1966, De Gregorio \& Jong-Wha, 2002, Bordean \& Sonea, 2018), on the improvement of the health level (Lochner, 2011, Mattos, 2012), living standards improvement (MigalaWarchol, 2018), on social inclusion and public society development (Center for Global Development, 2006, Estes, 1995), global competitiveness (Kiselakova et al., 2018).

More complex studies regarding the relationship between education and sustainable development were also carried out (Didham, 2015, Bhandari, 2017, Gupta, 2017, Tvaronavičiené, 2018, Fomina et al., 2018, Kowo et al., 2019, Atkočiūnienè \& Miroshnychenko, 2019). They were often limited by the level of the separate country (Malyarets et al., 2019, Mohanty \& Dash, 2018, Dannenberg $\&$ Grapentin, 2016) or a community (Karnitis, 2017, Petrushenko et al. (2014).

\section{Methodology of research}

In order to investigate the nature of impact, made by the state regulation of education to achieve sustainable development goals, statistic data for 2006-2016 among 14 Central and Eastern Europe countries (Belarus, Bulgaria, the Czech Republic, Estonia, Hungary, Latvia, Lithuania, Moldova, Poland, Romania, Slovakia, Slovenia, the Russian Federation, Ukraine) were selected. Their selection was caused by a number of common features in the historical and cultural development, geographical closeness and relative comparability of the statistic indicators. The current information is represented by means of the panel data, which have their own peculiarities in the analysis. In order to reveal the regression dependence during the panel data analysis, models with fixed or random effects are used. During the carried out comparison (Hausman test, comparison of results) a model with fixed effects was chosen. Thus, the equation will be as follows (Stock \& Watson, 2007, Yevdokimov et al., 2018): 


$$
Y_{i t}=\beta_{1} X_{i t}+\alpha_{i}+u_{i t}
$$

where $Y_{i t}-$ the dependent variable, where $i$ - entity, $t$ - year;

$\beta_{1}-$ a coefficient near X;

$X_{i t}$ - independent variable;

$\alpha_{i} \quad-$ the unknown intercept for each entity

$u_{i t}-$ error term

It is necessary to select the indicators for the dependent variable, which describe the achievement level regarding certain goals of sustainable development. Although there are many works in this sphere, nowadays there is no methodology which will enable to follow the achievement of every goal among 17 approved ones in sustainable development. Besides, it was revealed that today, not all countries keep the statistical records of the detailed tasks and indicators within every goal. It greatly complicates the deep analysis to achieve the set landmarks and to form the integral evaluation for the comparison at the international level.

In this regard, in order to carry out our research, it was decided to develop own instruments of the integral expression of the global goals in the sustainable development at the level of the selected Central and Eastern Europe countries.

For that purpose, the statistic data massive of the World Bank, which has a separate base, called Sustainable Development Goals (SDGs), was used. Let us notice that indicators, shown there, may not totally comply with indices, given by the UNO to monitor the sustainable development, however, it is the closest and fullest at the world level.

According to some indicators the SDGs there was no statistic information that caused the necessity to exclude them from the study.

Thus, according to every SDG, the integral indicator was formed. It provided the following stages:

1) normalization of indicators;

2) identification of every component weight by the method of the principal-component factors $(\mathrm{PCF})$;

3) calculation of the integral indicator.

At the first stage, the indicators were normalized. It distinguished stimulators (i.e. those, the increase of which will lead to the general index improvement by the goal) and destimulators (vice versa to the previous ones) and compared the initial data with the maximum and minimum value. For this purpose the following formulas are used (2 - 3):

- for indicators of stimulators:

$$
\bar{y}_{i j}=\frac{y_{i j}-y_{\text {min }}}{y_{\text {max }}-y_{\text {min }}},
$$


where $\quad \bar{y}_{i j}-$ a normalized $i$-indicator in $j$-year;

$y_{i j} \quad-i$-indicator in $j$-year;

$y_{\min }-$ minimum $i$-indicator by all years;

$y_{\max }-$ maximum $i$-indicator by all years.

- for indicators of destimulators:

$$
\bar{y}_{i j}=\frac{y_{\max }-y_{i j}}{y_{\max }-y_{\min }},
$$

As a result, all indicators take values from 0 to 1 and are completely comparable between each other for further stages in calculations.

Then the normalized data are analyzed by the method of principlecomponent factors (PCF), carried out automatically in STATA 11.1. As a result, the optimal number of factors (cumulative dispersion of which is not less than 75$85 \%$ ) is defined. Kaiser criterion, as well as scree plot, were used to confirm the results.

\section{Empirical results}

Let us show the results of PCF implementation to obtain the integral indicator by the SDG№2, which has only three indices (cereal yield (kg per hectare), the prevalence of anaemia among women of reproductive age (\% of women ages 15-49), the prevalence of undernourishment (\% of the population)) in Table 1.

Table 1. Intermediate results of calculations PCF by SDG№2

\begin{tabular}{|l|c|c|c|c|}
\hline Factor & Eigenvalue & Difference & Proportion & Cumulative \\
\hline Factor1 & 1.26069 & 0.16419 & 0.4202 & 0.4202 \\
\hline Factor2 & 1.09649 & 0.45367 & 0.3655 & 0.7857 \\
\hline Factor3 & 0.64282 & $\cdot$ & 0.2143 & 1.0000 \\
\hline \multicolumn{5}{|c|}{ Factor loadings (pattern matrix) and unique variances } \\
\hline \multicolumn{2}{|c|}{ Factor1 } & Factor2 & Uniqueness \\
\hline var1 & 0.8474 & 0.1126 & 0.2692 \\
\hline var2 & \multicolumn{2}{|c|}{0.6482} & -0.6046 & 0.2143 \\
\hline var3 & \multicolumn{2}{|c|}{0.3499} & 0.8475 & 0.1593 \\
\hline
\end{tabular}

(Source: Authors' calculations) 
As we can see from the above table, two factors, which had a cumulative dispersion of $78.57 \%$, comply with our conditions. In order to confirm our decision, let us give the scree plot graphic in Fig. 1. As we can see, the highest delay point of own indices falling down is at the level of 2 , that confirms our conclusions.

Figure 1. Scree plot of eigenvalues after factor

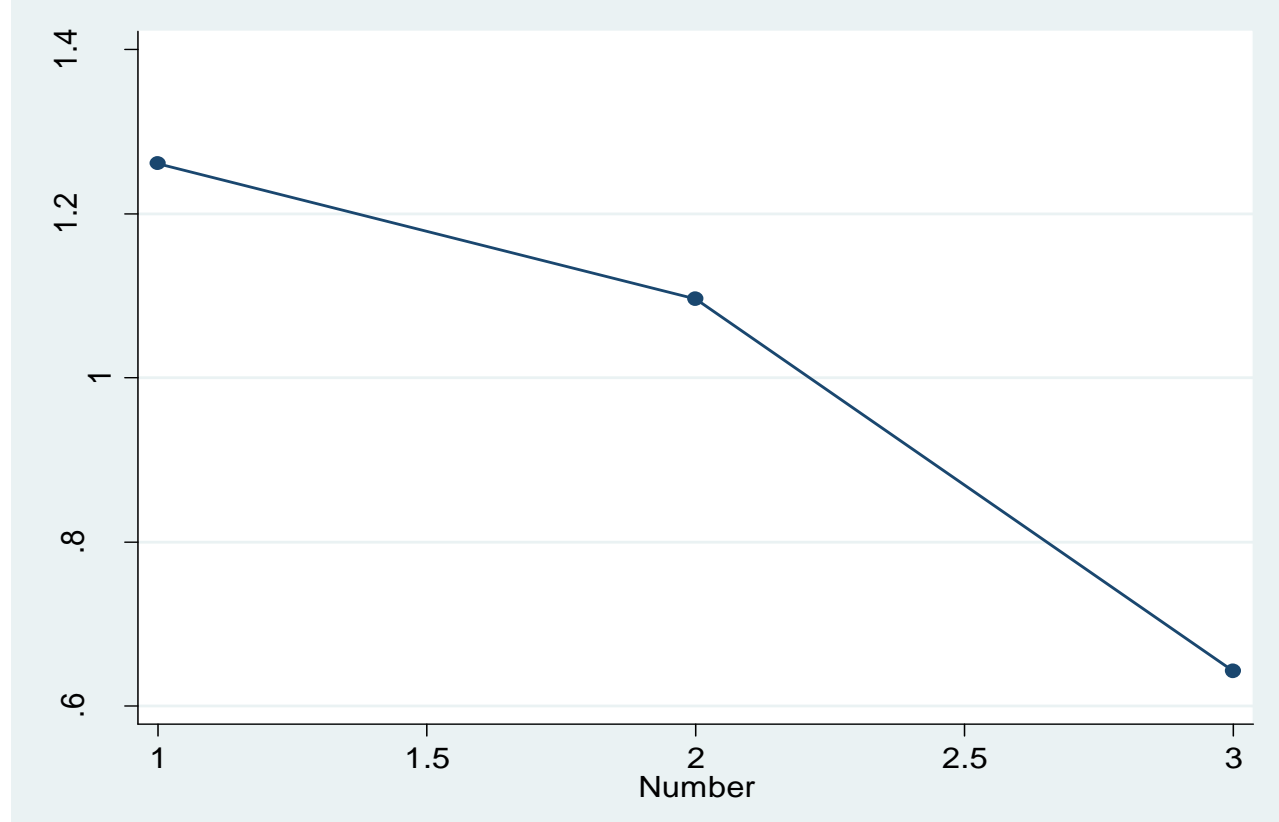

(Source: Authors' calculations)

PCF also let to obtain the factor load of every variable in the selected factors, which is formed depending on their correlation and dispersion share. Within our study, we choose values which exceed 0.6-0.7. The selected factor loads are used to calculate the weight of every variable. For this purpose the following formula (4) is used:

$$
w_{i}=\frac{f_{i} * d_{k}}{\sum_{k} f_{i} * d_{k}},
$$

where $w_{k}$ - weight of $i$-indicator;

$f_{k}$ - factor load of $i$-indicator;

$d_{k}$ - share of general dispersion of $k$-factor.

The integrated indicator, which describes SDGP№2, will be calculated by the following formula (5), which provides the weighing of the normalized data for the calculated weight for them: 


$$
I_{l m}=\sum \bar{y}_{i j} * w_{i},
$$

where $I_{l m}$ - integral indicator, which describes the labour market state during $j$-year.

As a result, the following integral indicators on SDG№2 were obtained for the selected countries, which we will compare with SDG№1 for 2006 and 2016.

Figure 2. Comparison of the integral indicators regarding the SDG№1 and SDG№2 for 2006 and 2016 in some countries of Central and Eastern Europe

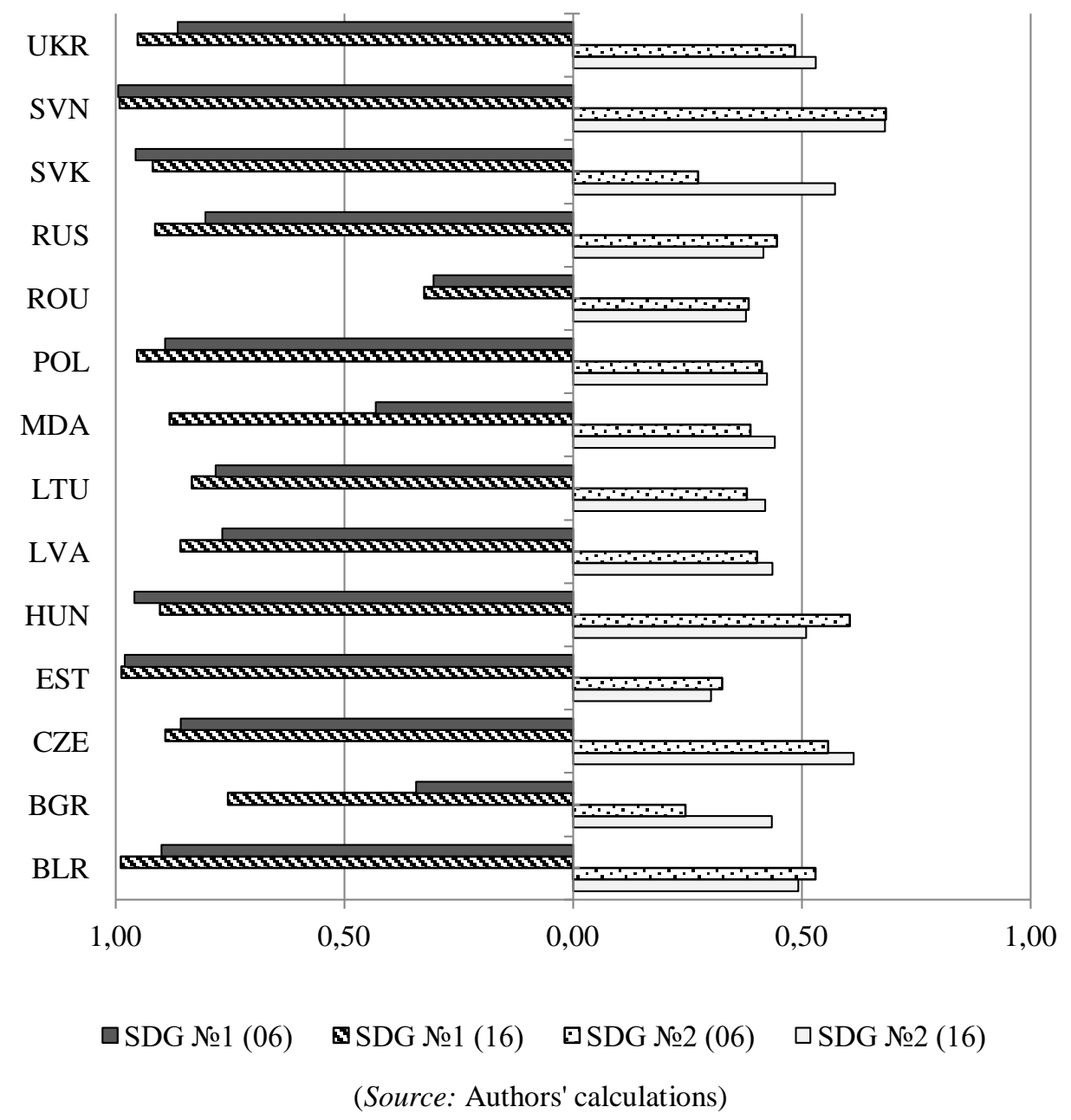


As we can see there is another dynamic to achieve the sustainable development goals in the selected countries by these two goals. In general, the integral indicators by SDG№1 to prevent poverty were slightly increased. It was caused by the crisis phenomena in the economy of these countries. According to SDG№2, the indicator is improved in most countries, and it solved the problem of poverty and agricultural development.

The similar calculations were carried out for all other SDGs (integrated indicators for 2016 are given in Figure 3). Thus, massive of dependent variables were formed $-\mathrm{Y}$.

Analyzing the above diagrams, one can say that sustainable development goals are achieved at different levels. The lowest indicators have goals 17 (to establish the partnership), 9 (industry, innovations, and infrastructure), 15 (to protect and to restore the land ecosystem), 11 (sustainable development of cities and communities) and 5 (gender equity). Let us mention that the Russian Federation is essentially distinguished by these goals. It is caused by the fact that they include indicators, which are measured in the natural units, and this country has a huge area.

We propose to use separate indicators, which describe the state regulation of the education sector in this or that country, as independent variables (X). Based on the general theoretical facts about education policy, its state regulation main areas include the formation of:

-a general strategy of the country's education sector development and its operational tasks and directions;

-the only legal field, which complies with the international standards and lets to achieve the fixed goal at various levels;

-the effective and modern infrastructure of the education sector, considered as a net of the educational providers to perform the educational activities;

-a system of the staffing support for the education sector,

- a financial provision system of the education sector.

The most general indicators, which describe the education policy of this or that country are the duration of compulsory education (years) and gross enrolment ratio from primary to tertiary $(\%)$.

In order to analyze the staffing support of the state regulation in the education sector, one proposed to use such indicators as the student-teacher ratio at different education levels (pre-primary, primary, secondary and tertiary education), which shows in average how many students are given to one lecturer. The most direct method of the state regulation in the education sector is its financial provision, which is proposed to be used by means of the following indicators government expenditure on education (PPP\$, millions). 
The influence of state regulation of education for achieving the sustainable development goals: case study of Central and Eastern European countries

Figure 3. Integral indicators by SDGs for 2016

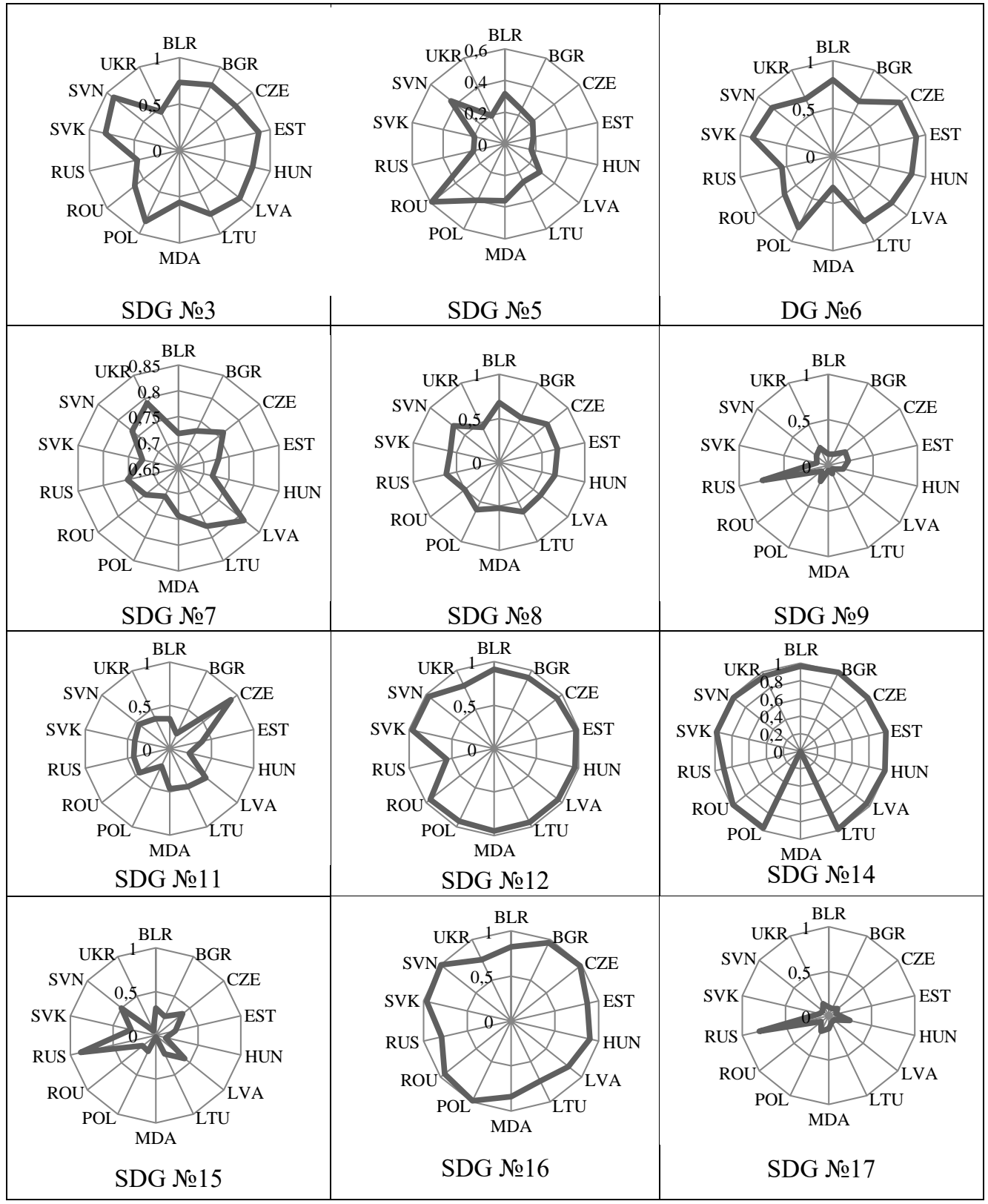

(Source: Authors' calculations) 
The influence of state regulation of education for achieving the sustainable development goals: case study of Central and Eastern European countries

First of all, we propose to investigate the selected indicators with the help of the Descriptive statistics module (Table 2).

Table 2. Descriptive statistics for the set of independent variables

\begin{tabular}{|c|c|c|c|c|c|}
\hline Variable & Observations & Mean & $\begin{array}{c}\text { Standard } \\
\text { deviation }\end{array}$ & Minimum & Maximum \\
\hline $\mathrm{x} 1$ & 84 & 18258.56 & 32012.14 & 857.67 & 139931.90 \\
\hline $\mathrm{x} 2$ & 84 & 9.88 & 1.12 & 9.00 & 13.00 \\
\hline $\mathrm{x} 3$ & 84 & 89.14 & 8.03 & 69.00 & 100.43 \\
\hline $\mathrm{x} 4$ & 84 & 11.59 & 3.53 & 5.67 & 19.30 \\
\hline $\mathrm{x} 5$ & 84 & 14.85 & 3.00 & 9.32 & 20.62 \\
\hline $\mathrm{x} 6$ & 84 & 9.84 & 1.77 & 6.72 & 13.23 \\
\hline $\mathrm{x} 7$ & 84 & 15.52 & 5.19 & 8.38 & 33.06 \\
\hline $\begin{array}{l}\text { where x1 - government expenditure on education, PPP\$ (millions); x2 - compulsory } \\
\text { education, duration (years); x3 - gross enrolment ratio, primary and secondary, both sexes } \\
\text { (\%); x4 - student-teacher ratio in pre-primary education (headcount basis); x5 - student- } \\
\text { teacher ratio in primary education (headcount basis); x6 - student-teacher ratio in } \\
\text { secondary education (headcount basis); x7 - student-teacher ratio in tertiary education } \\
\text { (headcount basis) }\end{array}$
\end{tabular}

(Source: Authors' calculations)

Based on the initial and obtained data, we can define that the Russian Federation had more expenditure for education in absolute terms (although in the percentage terms its share varies within $4 \%$ as $\%$ from GDP). Moldova had the lowest share for education in the absolute terms (although its share from GDP was 7-8\%). People, who study, have to spend from 9 years (Bulgaria, Belarus, Estonia Lithuania, Moldova, Slovenia for 2016) to 13 years in Hungary for education. Gross enrolment ratio also varies, its lowest value was observed in Moldova in 2010 (68.99\%), which slightly increased to $70.41 \%$ in 2016; the highest - Belarus. The student-teacher ratio at different levels also varies and it influences the education process quality in a certain way. The lowest values were in Estonia (2010) in the pre-school education, Poland (2010) in the primary education, Ukraine (2010) in the secondary education and Estonia (2012) in the higher education.

Having analyzed the incoming data let us start the regression analysis, the aim of which consists in the detecting of dependencies between separate indicators of the state regulation in the education sector and sustainable development goals. Let us notice that the 4 th goal forms the state regulation of education. That is why it as excluded from the research. 
As a result of the single-factor regression dependencies construction, it was found that government funding has the most significant influence on the sustainable development goals achievement. According to the obtained results, the direct essential link with the following goals was proved (Table 3):

- Goal 6. To ensure availability and sustainable management of water and sanitation for all (Y6);

- Goal 8. To promote sustained, inclusive and sustainable economic growth, full and productive employment and decent work for all (Y8);

- Goal 9. To build resilient infrastructure, promote inclusive and sustainable industrialization and foster innovation (Y9);

- Goal 12. To ensure sustainable consumption and production patterns (Y12);

- Goal 14. To conserve and sustainably to use the oceans, seas and marine resources for sustainable development (Y14);

- Goal 16. To promote peaceful and inclusive societies for sustainable development, to provide access to justice for all and build effective, accountable and inclusive institutions at all levels (Y16);

- Goal 17. To strengthen the means of implementation and to revitalize the Global Partnership for Sustainable Development (Y17).

Table 3. Results of the regression analysis by the indicator $x 1$ (government expenditure on education)

\begin{tabular}{|c|c|c|c|c|c|}
\hline Variable & $\begin{array}{c}\text { Coefficient } \\
\text { of } \mathbf{x}\end{array}$ & $\begin{array}{c}\text { Standard } \\
\text { error }\end{array}$ & $\mathbf{t}$ & $\mathbf{P}>|\mathbf{t}|$ & $\mathbf{R}$-sq \\
\hline Y6 & 0.380 & 0.093 & 4.070 & 0.000 & 0.593 \\
\hline Y8 & 0.523 & 0.201 & 2.600 & 0.011 & 0.521 \\
\hline Y9 & 0.251 & 0.049 & 5.140 & 0.000 & 0.844 \\
\hline Y12 & 0.452 & 0.099 & 4.580 & 0.000 & 0.785 \\
\hline Y14 & 0.499 & 0.045 & 11.180 & 0.000 & 0.936 \\
\hline Y16 & 0.498 & 0.185 & 2.680 & 0.009 & 0.521 \\
\hline Y17 & 0.169 & 0.063 & 2.670 & 0.010 & 0.897 \\
\hline
\end{tabular}

(Source: Authors' calculations)

As for the other indicators of the state regulation of education, distinguished by us earlier, the weak and relevant link with the following directions was proved (Table 4): 
The influence of state regulation of education for achieving the sustainable development goals: case study of Central and Eastern European countries

\section{Table 4. Confirmed adequate relationships according to the results of the regression analysis}

\begin{tabular}{|c|c|}
\hline $\begin{array}{c}\text { Indicator } \\
\text { (independent } \\
\text { variable) }\end{array}$ & SDGs (dependent variables) \\
\hline $\begin{array}{l}\text { Gross enrolment ratio } \\
\text { from primary to } \\
\text { tertiary }(\%)\end{array}$ & $\begin{array}{l}\text { Goal 2. To end hunger, to achieve food security and improved } \\
\text { nutrition and to promote sustainable agriculture } \\
\text { Goal 3. To ensure healthy lives and to promote well-being for all } \\
\text { at all ages } \\
\text { Goal } 6 \text {. To ensure availability and sustainable management of } \\
\text { water and sanitation for all } \\
\text { Goal } 8 \text {. To promote sustained, inclusive and sustainable } \\
\text { economic growth, full and productive employment and decent } \\
\text { work for all } \\
\text { Goal 12. To ensure sustainable consumption and production } \\
\text { patterns } \\
\text { Goal 14. To conserve and sustainably use the oceans, seas and } \\
\text { marine resources for sustainable development } \\
\text { Goal 16. To promote peaceful and inclusive societies for } \\
\text { sustainable development, to provide access to justice for all and } \\
\text { build effective, accountable and inclusive institutions atl levels }\end{array}$ \\
\hline $\begin{array}{l}\text { Student - teacher ratio } \\
\text { in pre-primary } \\
\text { education }\end{array}$ & $\begin{array}{l}\text { Goal 1. To end poverty in all its forms everywhere } \\
\text { Goal 16. To promote peaceful and inclusive societies for } \\
\text { sustainable development, to provide access to justice for all and } \\
\text { build effective, accountable and inclusive institutions at all levels }\end{array}$ \\
\hline $\begin{array}{l}\text { Student - teacher ratio } \\
\text { in primary education }\end{array}$ & $\begin{array}{l}\text { Goal 9. To build resilient infrastructure, to promote inclusive and } \\
\text { sustainable industrialization and foster innovation } \\
\text { Goal 14. To conserve and sustainably use the oceans, seas and } \\
\text { marine resources for sustainable development } \\
\text { Goal 16. To promote peaceful and inclusive societies for } \\
\text { sustainable development, to provide access to justice for all and } \\
\text { build effective, accountable and inclusive institutions at all levels }\end{array}$ \\
\hline $\begin{array}{l}\text { Student - teacher ratio } \\
\text { in secondary education }\end{array}$ & $\begin{array}{l}\text { Goal 6. To ensure availability and sustainable management of } \\
\text { water and sanitation for all } \\
\text { Goal } 7 \text {. To ensure access to affordable, reliable, sustainable and } \\
\text { modern energy for all } \\
\text { Goal } 15 \text {. To protect, restore and to promote sustainable use of } \\
\text { terrestrial ecosystems, sustainably manage forests, combat } \\
\text { desertification, and halt and reverse land degradation and halt } \\
\text { biodiversity loss }\end{array}$ \\
\hline
\end{tabular}


The influence of state regulation of education for achieving the sustainable development goals: case study of Central and Eastern European countries

\begin{tabular}{|c|c|}
\hline $\begin{array}{l}\text { Indicator } \\
\text { (independent } \\
\text { variable) }\end{array}$ & SDGs (dependent variables) \\
\hline $\begin{array}{l}\text { Student - teacher ratio } \\
\text { in tertiary education }\end{array}$ & $\begin{array}{l}\text { Goal 2. To end hunger, achieve food security and improved } \\
\text { nutrition and promote sustainable agriculture } \\
\text { Goal 3. To ensure healthy lives and promote well-being for all at } \\
\text { all ages } \\
\text { Goal 6. To ensure availability and sustainable management of } \\
\text { water and sanitation for all } \\
\text { Goal } 8 \text {. To promote sustained, inclusive and sustainable } \\
\text { economic growth, full and productive employment and decent } \\
\text { work for all } \\
\text { Goal 12. To ensure sustainable consumption and production } \\
\text { patterns } \\
\text { Goal } 15 \text {. To protect, restore and to promote sustainable use of } \\
\text { terrestrial ecosystems, sustainably manage forests, combat } \\
\text { desertification, and halt and reverse land degradation and halt } \\
\text { biodiversity loss }\end{array}$ \\
\hline $\begin{array}{l}\text { Duration of } \\
\text { compulsory education }\end{array}$ & $\begin{array}{l}\text { Goal 8. To promote sustained, inclusive and sustainable } \\
\text { economic growth, full and productive employment and decent } \\
\text { work for all }\end{array}$ \\
\hline
\end{tabular}

(Source: Authors' calculations)

\section{Conclusions}

Concluding the above research, one can confirm that the state activities in the education sector have a great influence on the achievement of sustainable development goals. It is caused not only by the fact that the goal №4 is "to provide inclusive and fair qualitative education and to encourage the opportunities to study during the whole life for everybody", but also by understanding that only high educated nation will be able to have a rational lifestyle, which will promote the economic, ecological and social prosperity and development.

The empiric results of the carried out research additionally confirm it. They prove that the most effective instrument within the state regulating tools for the education sector is its funding, which helps to achieve the countries' economic (goal 8, goal 9, goal 12), ecological (goal 6, goal 14) and social (goal 16, goal 17) development. Less effective instruments and those which have the impact on the achievement of sustainable development goals are such tools, which are usually prescribed within the current education policy: gross enrolment ratio, duration of compulsory education ta student-teacher ratio.

\section{Authors Contributions}

The authors listed have made a substantial, direct and intellectual contribution to the work, and approved it for publication. 


\section{Conflict of Interest Statement}

The authors declare that the research was conducted in the absence of any commercial or financial relationships that could be construed as a potential conflict of interest.

\section{Acknowledgements and research funding}

The article was executed in the framework of state budget scientific research works: Registration No. 0118 U003569 and Registration No. 0117 U003935.

\section{References}

Agheorghiesei, D.-T., Sorin, G., Airinei, D. (2018). The impact of financial crisis on the quality of higher education system. An exploratory study from the perspective of the vulnerability perceived by the students. Transformations in Business \& Economics, Vol. 17, No 2B (44B), 721-738.

Anatan, L. (2018). An institutional perspective of knowledge transfer within university and industry alliance. International Journal of Economic Policy in Emerging Economies, 11(4), 378-395.

Androniceanu A., Sabie O. M. \& Pegulescu A. (2020). An integrated approach of the human resources motivation and the quality of health services.Theoretical and Empirical Research in Urban Management, 15(1), February, 42-53.

Androniceanu, A. (2019a). The social sustainability of smart cities: urban technological innovation, big data management, and the cognitive internet of things. Geopolitics, History, and International Relations 11(1), 110-115. doi:10.22381/GHIR11120197

Androniceanu A. (2019b). Using automated digital systems to thoroughly regulate social governance: monitoring and behavior modification through data-driven algorithmic decision-making. Contemporary Readings in Law and Social Justice, Volume 11, Issue 1, pp.63-68.

Androniceanu, A. (2019c). Social responsibility, an essential strategic option for a sustainable development in the field of bio-economy, Amfiteatru Economic, 21(52), 347-364.

Atkočiūnienė, Z. O.; Miroshnychenko, O. (2019). Towards sustainable development: the role of R\&D spillovers in innovation development. Journal of Security and Sustainability Issues, 9(2), 409-419. https://doi.org/10.9770/jssi.2019.9.2(4).

Baburina, N. A., Tarkhanova, E. A., \& Fedorova, O. B. (2017). Innovational approaches to attracting people savings in the modern economy. Marketing and Management of Innovations, (3), 187-197.

Balcerzak, A. P., Pietrzak, M. B. (2016), Quality of Institutions for Knowledge-based Economy within New Institutional Economics Framework. Multiple Criteria Decision Analysis for European Countries in the Years 2000-2013, Economics and Sociology, 9(4), 66-81. DOI: 10.14254/2071-789X.2016/9-4/4. 
Bayar, Y., Remeikiene, R., Androniceanu, A., Gaspareniene, L., \& Jucevicius, R. (2020). The shadow economy, human development and foreign direct investment inflows. Journal of Competitiveness, 12(1), 5-21. https://doi.org/10.7441/joc.2020.01.01

Becker G. S., Chiswick B. R. (1966) Education and the Distribution of Earnings, The American Economic Review, 56(1/2), 358-369.

Benos, N., Zotou, S. (2014) Education and Economic Growth: A Meta-Regression Analysis, World Development, 64, 669-689.

Bercu, A.-M.; Tofan, M.; Cigu, E.; Petrisor, M.-B. (2019). The government effectiveness drivers and growth. Empirical evidence from CEE countries. Transformations in Business \& Economics, 18(2A), 553-567.

Bhandari, M.P., Bhattarai, K. (2017). Institutional Architecture for Sustainable Development (SD): A Case Study from Bangladesh, India, Nepal, and Pakistan. SocioEconomic Challenges, 1(3), 6-21. DOI: 10.21272sec.1.1(3).6-21.

Bilan, Y.(a), Raišienè, A.G., Vasilyeva, T., Lyulyov, O., Pimonenko, T. (2019). Public Governance efficiency and macroeconomic stability: Examining convergence of social and political determinants. Public Policy and Administration, 18 (2), 241-255.

Bilan, Y.(b), Vasilyeva, T., Lyeonov, S., Bagmet, K. (2019). Institutional complementarity for social and economic development. Business: Theory and Practice, 20, 103-115.

Bilan, Y.(c), Vasilyeva, T., Kryklii, O., Shilimbetova, G. (2019). The creative industry as a factor in the development of the economy: Dissemination of European experience in the countries with economies in transition. Creativity Studies, 12 (1), 75-101.

Bilan, Y. (d), Brychko, M., Buriak, A., Vasilyeva, T. (2019). Financial, business and trust cycles: The issues of synchronization. Zbornik Radova Ekonomskog Fakultet au Rijeci, 37 (1), 113-138.

Bilan, Y. (e), Lyeonov, S., Lyulyov, O., Pimonenko, T. (2019). Brand management and macroeconomic stability of the country. Polish Journal of Management Studies, 19 (2), 61-74.

Bilan, Y. (f), Đšuzmenko, Đž., Boiko, A. (2019). Research on the impact of industry 4.0 on entrepreneurship in various countries worldwide. Proceedings of the $33^{\text {rd }}$ International Business Information Management Association Conference, IBIMA 2019: Education Excellence and Innovation Management through Vision 2020, pp. 2373-2384.

Bilan, Y., Lyeonov, S., Vasylieva, T., Samusevych, Y. (2018). Does tax competition for capital define entrepreneurship trends in Eastern Europe? Online Journal Modelling the New Europe. 27. 34-66. DOI: 10.24193/OJMNE.2018.27.02.

Bilan, Y., Vasilyeva, T., Lyulyov, O., Pimonenko, T. (2019). EU vector of Ukraine development: Linking between macroeconomic stability and social progress. International Journal of Business and Society, 20 (2), 433-450.

Bondar, A., Paszkowski, J. (2019). Intellectual capital as a factor of co-operation between the countries of the eastern partnership and the European Union. Polish Journal of Management Studies, 20 (1), 78-91. doi: 10.17512/pjms.2019.20.1.07.

Bordean, O. N.; Sonea, A. (2018). Student satisfaction and perceived skills: any link to employability?, Entrepreneurship and Sustainability Issues, 6(1), 356-370. https://doi.org/10.9770/jesi.2018.6.1(22) 
The influence of state regulation of education for achieving the sustainable development goals: case study of Central and Eastern European countries

Borocki, J., Radisic, M., Sroka, W., Greblikaite, J., Androniceanu, A. (2019). Methodology for strategic posture determination of SMEs - the case from a developing country. Inžinerinè Ekonomika-Engineering Economics, 30(3), 265-277.

Brychko, M., Semenog, A. (2018). Efficiency as a new ideology of trust-building corporate governance. Business and Economic Horizons, 14 (4), 913-925.

Center for Global Development (2006) Education and the Developing World: Why is education essential for development, Rich World, Poor World: A Guide to Global Development, Washington, D.C.: CGD.

Churchill, S. A., Ugur, M., Yew, S. L. (2017) Government education expenditures and economic growth: a meta-analysis, The B.E. Journal of Macroeconomics, De Gruyter, 17(2), pp. 1-17.

Chygryn, O., Petrushenko, Y., Vysochyna, A., \& Vorontsova, A. (2018). Assessment of fiscal decentralization influence on social and economic development. Montenegrin Journal of Economics, 14(4), 69-84. doi:10.14254/1800-5845/2018.14-4.5

Dannenberg, S., Grapentin, T. (2016) Education for Sustainable Development - Learning for Transformation. The Example of Germany, Journal of Futures Studies, 20(3), 7-20.

De Gregorio J., Jong-Wha L. (2002) Education and Income Inequality: New Evidence from Cross Country Data. Review of Income and Wealth, 48 (3), 395-416.

Didham, R.J., Ofei-Manu, P. (2015) Chapter 5. The Role of Education in the Sustainable Development Agenda: Empowering a learning society for sustainability through quality education. Achieving the Sustainable Development Goals: From agenda to action, Hayama, Institute for Global Environmental Strategies, p.207.

Estes, R. (1995) Education for social development: curricular issues and models. Social Development Issues, 16(3), 68-90.

Fomina, A. V.; Berduygina, O. N.; Shatsky, A. A. (2018). Industrial cooperation and its influence on sustainable economic growth. Entrepreneurship and Sustainability Issues, 5(3), 467-479. https://doi.org/10.9770/jesi.2018.5.3(4).

Golovchanskaya, E.E., Strelchenya, E.I., Popkova, E.G., Leonenko, O.V. (2018). The key role of intellectual resources in the economic growth models in the institutional environment of innovative activity of the Republic of Belarus: theory and practice. International Journal of Trade and Global Markets (IJTGM), Vol. 11, No. 3.

Grenäãkovã, A., Bilan, Y., Samusevych, Y., Vysochyna, A. (2019). Drivers and inhibitors of entrepreneurship development in central and eastern European countries. Proceedings of the $33^{\text {rd }}$ International Business Information Management Association Conference, IBIMA 2019: Education Excellence and Innovation Management through Vision 2020, pp. 2536-2547.

Gupta R. (2017). Socioeconomic challenges and its inhabitable global illuminations. Socio Economic Challenges, 1(1), 81-85. DOI: 10.21272/sec.2017.1-10.

Guziejewska, B., Majdzińska, A. (2018). The model of municipal education expenditures in Poland. Policy, budget and demography. Equilibrium. Quarterly. Journal of Economics and Economic Policy, 13(3), 523-541. https://doi.org/10.24136/eq.2018.026.

Haseeb, M., Hussai, H. I., Kot, S., Androniceanu, A., Jermsittiparsert, K. (2019). Role of social and technological challenges in achieving a sustainable competitive advantage and sustainable business performance. Sustainability, 11(14), Article Number: 3811 
Indiyati, D. (2018). The role of organisational culture, intellectual capital and competitive advantage in supporting the government policies in education. International Journal of Economic Policy in Emerging Economies, 11 (1/2), 68-82.

Jikia G., Vorontsova, A., Petrushenko Yu., (2017). Measuring Efficiency of Financial Support in Lifelong Learning System: A Case Study of Ukrainian Regions. Business Ethics and Leadership, 1(4), 84-92. DOI: 10.21272/bel.1(4).84-92.

Karnitis, G., \& Karnitis, E. (2017). Sustainable growth of EU economies and Baltic context: Characteristics and modelling. Journal of International Studies, 10(1), 209-224. doi:10.14254/2071-8330.2017/10-1/15

Kiselakova, D., Sofrankova, B., Cabinova, V., Onuferova, E., Soltesova, J. (2018). The Impact of R\&D Expenditure on the Development of Global Competitiveness within the CEE EU Countries. Journal of Competitiveness, 10(3), 34-50. https://doi.org/10.7441/joc.2018.03.03.

Kohnová, L., Papula, J., Salajov,á N. (2019). Internal factors supporting business and technological transformation in the context of Industry 4.0. Business: Theory and Practice, 20, 137-145. https://doi.org/10.3846/btp.2019.13.

Kolosok, S., Dementov, V., Korol, S., \& Panchenko, O. (2018). Public policy and international investment position in European integration of Ukraine. Journal of Applied Economic Sciences, 13(8), 2375-2384.

Kolosok, S., Dementov, V., Korol, S., Panchenko, O. (2018). Public policy and international investment position in european integration of Ukraine. Journal of Applied Economic Sciences, 13 (8), pp. 2375-2384.

Kolosok, S., Myroshnychenko, I. (2015). Structural change and business cycle dynamics in transition economies. Journal of Applied Economic Sciences, 10(1), 128-141.

Kouassi K. B. (2018). Public Spending and Economic Growth in Developing Countries: a Synthesis. Financial Markets, Institutions and Risks, 2(2), 22-30. DOI: 10.21272/fmir.2(2).22-30.

Kowalska, I. (2016). Sources of financing knowledge-based economy: the case of formal, non-formal and informal education in Poland. Oeconomia Copernicana, 7(1), 75-90. https://doi.org/10.12775/OeC.2016.006.

Kowo, Ak.S., Owotutu, S. Ol., Adewale Ad. G. (2019). Enhancing the operational effectiveness of savings and credit cooperative societies for sustainable growth. Financial Markets, Institutions and Risks, 3(2), 59-68. http://doi.org/10.21272/ fmir.3(2).59-68.2019.

Kryk, B. (2016). Accomplishment of the European Union lifelong learning objectives in Poland. Oeconomia Copernicana, 7(3), 389-404. https://doi.org/10.12775/OeC.2016.023.

Kubak, M., Tkacova, A., Androniceanu, A., Tvaronavičienè, M., Huculova, E. (2018). Financial literacy of students in chosen universities - research platform for regulatory processes of educational system in Slovakia, E\&M Economics and Management, 2l(1), pp. 175-190. doi: 10.15240/tul/001/2018-1-012

Leicht, A., Heiss, J., Won Jung B. (2018) Issues and trends in education for sustainable development, UNESCO, Paris, p. 276. 
Lochner, L. (2011) Non-Production Benefits of Education: Crime, health, and good citizenship, Handbook of the economics of education, Vol. 4, Amsterdam: NorthHolland, pp. 183-282.

Lyeonov, S., Liuta, O. (2016). Actual problems of finance teaching in Ukraine in the post-crisis period. The Financial Crisis: Implications for Research and Teaching, pp. 145-152.

Lyeonov, S., Vasilyeva, Abaas, M. S. M., Chygryn, O., Kubatko, O., \& Pimonenko, T. (2018). Social and economic drivers of national economic development: The case of OPEC countries. Problems and Perspectives in Management, 16(4), 155-168. doi:10.21511/ppm.16(4).2018.14

Malyarets, L., Barannik, I., Sabadash, L., Grynko, P. (2019). Modeling the Economic Sustainability of the Macro System (for Example Ukraine). Montenegrin Journal of Economics, Economic Laboratory for Transition Research (ELIT), 15(3), 23-35.

Marekha, I. S. (2016). Market economic channel for intergenerational transmission of environmental values. Actual Problems of Economics, 180(6), 282-290.

Matošková, J. (2016). Measuring Knowledge. Journal of Competitiveness, 8 (4), 5-29 https://doi.org/10.7441/joc.2016.04.01

Mattos, T. V., MacKinnon, M. A., Boorse, D. F. (2012) The Intersection of Gender, Education, and Health: A community-level survey of education and health outcomes for women in southeastern Togo Gordon College, BIO381 Public Health Research, pp. 1-22.

Mazurek, J., Mielcová, E. (2019). On the relationship between selected socio-economic indicators and student performances in the PISA 2015 study. E+M Ekonomie a Management, 22, 22-39. 10.15240/tul/001/2019-2-002.w

Mendy, D., Widodo, T. (2018). Do education levels matter on Indonesian economic growth? Economics and Sociology, 11(3), 133-146. doi:10.14254/2071-789X.2018/ 11-3/8.

Migala-Warchol, A., Pasternak-Malicka, M. (2018). Living standards of EU Countries' residents: impact of education and innovation. Marketing and Management of Innovations, 4, 307-315. http://doi.org/10.21272/mmi.2018.4-26.

Mohanty, A., Dash, D. (2018) Education for sustainable development: A conceptual model of sustainable education for India, International Journal of Development and Sustainability, 7(9), 2242-2255.

Nicolescu, L., Tudorache, F.G., Androniceanu, A. (2020). Performance risk analysis on mutual funds versus stock exchanges in young financial markets Journal of International Studies, 13(1), 279-294. doi: 10.14254/2071-8330.2020/13-1/18

Palascakova, D., Kol’veková, Ga., Melas, D. (2019). Analysis of state investments into human capital in Slovak Republic. E+M Ekonomie a Management, 22, 114-128. 10.15240/tul/001/2019-2-008.

Palienko, M., Lyulyov, O. (2018). The impact of social factors on macroeconomic stability: empirical evidence for Ukraine and European Union countries. SocioEconomic Challenges, 2(1), 103-116. DOI: 10.21272/sec.2(1).103-116.

Pauhofova, I., Stehlikova, B, Kljucnikov, A , Androniceanu, A. (2018). Spatial and sectoral conditionality of the average monthly nominal wage in the Slovak Republic, Transformations in Business \& Economics, 17(3), 155-168. 
Peresadko, G.O., Kovalenko, E.V., Kulyk, L.A. (2014). Mechanisms of investing into innovative projects of enterprises. Actual Problems of Economics, 160 (1), 184-187.

Petrushenko, Y., Kostyuchenko, N., Smolennikov, D., Vorontsova, A. (2017). Impact of the participatory financing of international development projects on social capital of the local communities. Problems and Perspectives in Management, 15 (3), 183-192.

Petrushenko, Y.M., Kostyuchenko, N.M., Danko, Y.I. (2014). Conceptual framework of local development financing in UNDP projects in Ukraine. Actual Problems of Economics, 159 (9), 257-263.

Pikhotskyi, V., Nikolaienko, Y., Derii, Z., Zaitsev, O., Havryliuk, O., Dmytrenko, I. (2019). Modelling the impact of institutional environment on key macroeconomic indicators. International Journal of Engineering and Advanced Technology, 9 (1), 6957-6963.

Pitoňákova, R. (2019). Modelling impact of economic and demographic factors on personal saving rate in the euro area. International Journal of Trade and Global Markets, $12(3 / 4), 333-344$.

Pryima, S., Dayong, Y., Anishenko, O., Petrushenko, Y., Vorontsova, A. (2018). Lifelong learning progress monitoring as a tool for local development management. Problems and Perspectives in Management, 16 (3), 1-13.

Rahman, A., Tvaronaviciene, M. , Smrcka, L., Androniceanu, A. (2019). The effect of bank competition on the cost of credit: empirical evidence from the Visegrad Countries. Acta Polytechnica Hungarica, 16(4), 175-195. DOI: 10.12700/APH.16.4.2019.4.9

Raišienè, A. G., Bilan, S., Smalskys, V., Gečienè, J. (2019). Emerging changes in attitudes to inter-institutional collaboration: the case of organizations providing social services in communities. Administratie si Management Public, (33), 34-56, doi: $10.24818 / \mathrm{amp} / 2019.33-03$.

Rungsrisawat, S.; Pamornmast, C. (2019). Does the education, health and employment determine the economic growth: a case study. Journal of Security and Sustainability Issues, 9(2), 701-714. https://doi.org/10.9770/jssi.2019.9.2(26).

Serhii, I., Peresadko, G., Pidlisna, O., Kovalenko, E. (2014). Corporate social responsibility in marketing researches: Literature review. Corporate Ownership and Control, 11 (4 Continued 5), 499-503.

Shvindina, H. (2019). Coopetition as an emerging trend in research: Perspectives for safety \& security. Safety, 5 (3), art. no. 61.

Skliar, I. (2018). Towards the assurance of transparency and quality of higher education in Ukraine: National Qualification Framework. Business Ethics and Leadership, 2(1), 96-105. doi: 10.21272/bel.2(1).96-105.2018.

Smaliukienè, R., Bekešienè, S., Chlivickas, E., Magyla, M. (2017). Explicating the role of trust in knowledge sharing: a structural equation model test. Journal of Business Economics and Management, 18(4), 758-778. https://doi.org/10.3846/ 16111699.2017.1317019

Stock, J. H., Watson, M.W. (2007) Introduction to econometrics, 2nd ed., Boston: Pearson Addison Wesley, 840 p.

Tamulevičienè, D., Androniceanu, A. 2020. Selection of the indicators to measure an enterprise's value and its changes in the controlling system for medium-sized 
The influence of state regulation of education for achieving the sustainable development goals: case study of Central and Eastern European countries

enterprises. Entrepreneurship and Sustainability Issues, 7(3), 1440-1458. https://doi.org/10.9770/jesi.2020.7.3(1)

Tvaronavičienè, M., Tarkhanova, E., Durglishvili, N. (2018). Sustainable economic growth and innovative development of educational systems. Journal of International Studies, 11(1), 248-256. doi:10.14254/2071-8330.2018/11-1/19.

Vaiciukevičiūtė, A., Stankevičienė, J., Bratčikovienè, N. (2019). Higher education institutions' impact on the economy. Journal of Business Economics and Management, 20(3), 507-525. https://doi.org/10.3846/jbem.2019.10156.

Vasilyeva, T., Kuzmenko, O., Bozhenko, V., Kolotilina, O. (2019). Assessment of the dynamics of bifurcation transformations in the economy. CEUR Workshop Proceedings, 2422, pp. 134-146.

Vasilyeva, T., Lyeonov, S., Adamičková, I., Bagmet, K. (2018). Institutional Guality of Social Sector: the Essence and Measurements. Economics and Sociology, 11(2), 248-262. doi:10.14254/2071-789X.2018/11-2/17.

Vasylieva, T. A., Lieonov, S., V., Petrushenko, Yu. M., Vorontsova A. S. (2017) Investments in the system of lifelong education as an effective factor of socioeconomic development. Financial and Credit Activity-Problems of Theory and Practice, 2(23), 426-436.

Vasylyeva, T.A., Leonov, S.V., Lunyakov, O.V. (2014). Countercyclical capital buffer as a macroprudential tool for regulation of the financial sector. Actual Problems of Economics, 158 (8), 278-283.

Volchik, V., Oganesyan, A., \& Olejarz, T. (2018). Higher education as a factor of socioeconomic performance and development. Journal of International Studies, 11(4), 326-340. DOI:10.14254/2071-8330.2018/11-4/23

Vorontsova, A. S., Lieonov, S. V., Vasylieva, T. A., Artiukhov, A. Y. (2018). Innovations in the financing of lifelong learning system: expenditure optimization model. Marketing and Management of Innovations, 2, 218-231. http://doi.org/10.21272/ mmi.2018.2-18.

Vovk M., Braga D. (2017). Knowledge economy of the EU: strengths and weaknesses. Marketing and Management of Innovations, 4, 292-300, http://doi.org/10.21272/ mmi.2017.4-26.

Wierzbicka, W. (2018). Information infrastructure as a pillar of the knowledge-based economy - an analysis of regional differentiation in Poland. Equilibrium. Quarterly Journal of Economics and Economic Policy, 13(1), 123-139. https://doi.org/10.24136/eq.2018.007.

Yevdokimov, Y., Melnyk, L., Lyulyov, O., Panchenko, O., \& Kubatko, V. (2018). Economic freedom and democracy: Determinant factors in increasing macroeconomic stability. Problems and Perspectives in Management, 16(2), 279-290. doi:10.21511/ppm.16(2).2018.26.

Zakharkin, O., Basantsov, I., Shcherbachenko, V., ZakharkinĐ, L. (2019). Public-private partnership as an effective tool in R\&D activity. Proceedings of the $33^{\text {rd }}$ International Business Information Management Association Conference, IBIMA 2019: Education Excellence and Innovation Management through Vision 2020, pp. 6674-6678. 